\author{
W. Mao*, K. Bao**, G. Liu, H. Xie, C. Chen, L. Ye, B. Li, \\ X. Zhao \\ College of Chemistry and Pharmacy Engineering, Nanyang Normal \\ University, Henan, P. R. China \\ *maowutao@126.com \\ **baokeyan@126.com
}

\title{
Synthesis of orthorhombic chromium boride by solid state reaction
}

Chromium boride is characterized by interesting properties, like high melting point, hardness, and corrosion and abrasion resistances. In this paper a novel synthesis of chromium boride micropaticles via a solid-state route at $600{ }^{\circ} \mathrm{C}$ is reported. The $X$-ray diffraction pattern taken from the reaction product indicated that the product was orthorhombic chromium boride. The CrB particle size (about 1 2 $\mu \mathrm{m}$ ) is confirmed by FESEM and TEM images. Solid state reactions that were carried out in sealed autoclave systems provide an alternative, convenient, and environmentally friendly pathway for the fabrication of $\mathrm{CrB}$.

Keywords: solid state reactions, chromium boride, synthesis.

\section{INTRODUCTION}

Metal borides have been considered as advanced structural materials because of their high melting point, high hardness, oxidation resistance, excellent thermal and electrical properties [1-5]. Among these borides, chromiumboron is known for its application as anticorrosive, superhard coatings of high chemical stability. In the chromium-boron phase diagram, several binary phases $\left(\mathrm{Cr}_{5} \mathrm{~B}_{3}, \mathrm{CrB}, \mathrm{Cr}_{3} \mathrm{~B}_{4}, \mathrm{Cr}_{2} \mathrm{~B}_{3}\right.$, and $\left.\mathrm{CrB}_{2}\right)$ are known [6]. Among these, chromium boride $\mathrm{CrB}_{2}$ and $\mathrm{CrB}$ are the most important due to its interesting properties, like high melting point, hardness, resistivity, corrosion and abrasion resistances $[7,8]$. One of the issues with chromium boride is the difficult synthetic condition and presence of other binary borides as secondary phases. Synthesis of chromium boride has been carried out earlier by methods like combustion synthesis [9, 10], pulsed magnetron sputtering [11], and thermal evaporation process [12]. Qin and co-workers have synthesized chromium boride nanocrystalline via a solid-state reaction carried out in an autoclave by using $\mathrm{CrCl}_{3}, \mathrm{Mg}$, and $\mathrm{MgB}_{2}$ as the reactants [13]. Ma and co-workers have prepared chromium boride nanorods by reductionboronation route at $650{ }^{\circ} \mathrm{C}$ in molten salt in an autoclave [14]. Solid state reactions carried out in sealed autoclave systems provide an alternative, convenient and environmentally friendly pathway for fabrication of a wide range of non-oxide compound nanocrystals, for the systems can be isolated from air [15, 16]. CrB has interesting properties like high melting point, hardness, resistivity, corrosion, and abrasion resistance. In this work, $\mathrm{CrB}$ microparticles were successfully prepared by the reaction of $\mathrm{Cr}_{2} \mathrm{O}_{3}$ and $\mathrm{NaBH}_{4}$ in an autoclave at $600{ }^{\circ} \mathrm{C}$ for $10 \mathrm{~h}$. XRD pattern indicated that the product was orthorhombic $\mathrm{CrB}$. The sizes of $\mathrm{CrB}$ micropaticles were about $1-2 \mu \mathrm{m}$. 


\section{EXPERIMENTAL}

\section{Preparation of CrB micropaticles}

All the chemical reagents were purchased from Sinopharm Chemical Reagent Co., Ltd. and used without further purification. In a typical procedure, $\mathrm{Cr}_{2} \mathrm{O}_{3}$ $(0.50 \mathrm{~g})$, and $\mathrm{NaBH}_{4}(1.50 \mathrm{~g})$ were mixed and added in an autoclave of $20 \mathrm{~mL}$ capacity. The autoclave was sealed and heated in an electric stove with a heating ramp rate of $10{ }^{\circ} \mathrm{C} / \mathrm{min}$ and maintained at $600{ }^{\circ} \mathrm{C}$ for $10 \mathrm{~h}$, and then it was cooled to room temperature naturally. The precipitates in the autoclave were collected and washed with absolute ethanol, hot dilute hydrochloric acid, and distilled water several times to remove the impurity . The final product was dried in vacuum at $60{ }^{\circ} \mathrm{C}$ for $6 \mathrm{~h}$.

\section{Characterization}

Powder X-ray diffraction (XRD) measurement was carried out with a Philips

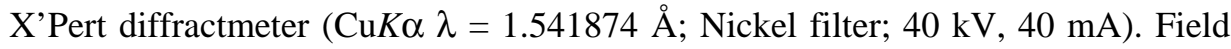
emission scanning electron microscope (FESEM) images were taken on a JEOL JSM-6300F SEM. Transmission electron microscopy (TEM) images, highresolution transmission electron microscopy (HRTEM) images and selected area electron diffraction (SAED) were performed on a JEOL JEM-2010 microscope operating at $200 \mathrm{kV}$.

\section{RESULTS AND DISCUSSION}

The Powder X-ray diffraction (XRD) pattern of the sample prepared at $600{ }^{\circ} \mathrm{C}$ is shown in Fig. 1. The diffraction peaks (110), (021), (111), (130, 040), (131, 041), (200), (002) and (221) are completely consistent with the standard card of orthorhombic CrB (JCPDS PDF No. 89-3587, $a=2.978 \AA, b=7.879 \AA$, $c=$ $2.934 \AA$ ). No evidences of the impurities such as $\mathrm{Cr}, \mathrm{B}$, and $\mathrm{Cr}_{2} \mathrm{O}_{3}$ can be found in the XRD pattern.

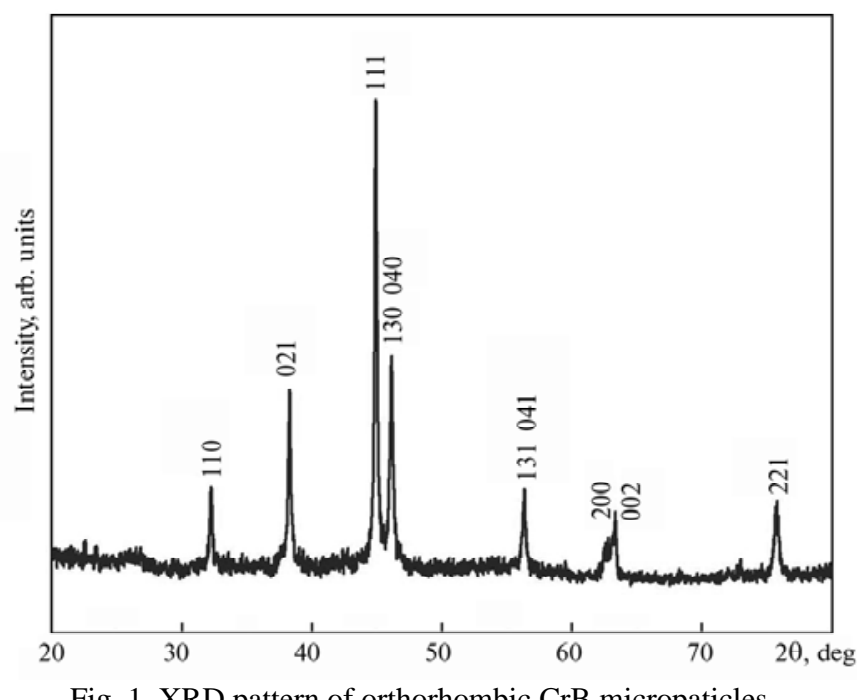

Fig. 1. XRD pattern of orthorhombic CrB micropaticles.

The morphology and structure of the as-prepared sample were further analyzed by FESEM. The CrB micropaticles were synthesized on a large scale, as revealed 
in Figs. 2, $a, b$ where a panoramic FESEM image of the product is displayed. Figure 2, $c$ presents a middle magnification FESEM image of the product, exhibiting that all particles were dense. The high magnification FESEM image (Fig. 2, $d$ ) indicates that the sizes of $\mathrm{CrB}$ micropaticles were about 1-2 $\mu \mathrm{m}$. The result confirms that this method can be used for preparing particles with homogeneous structures.

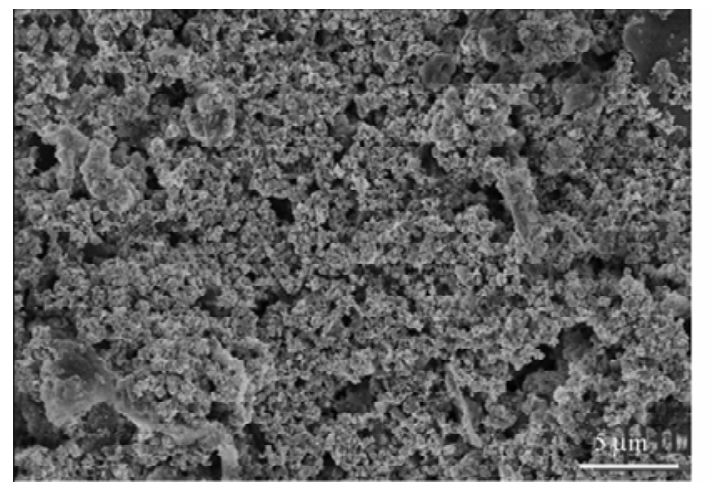

$a$

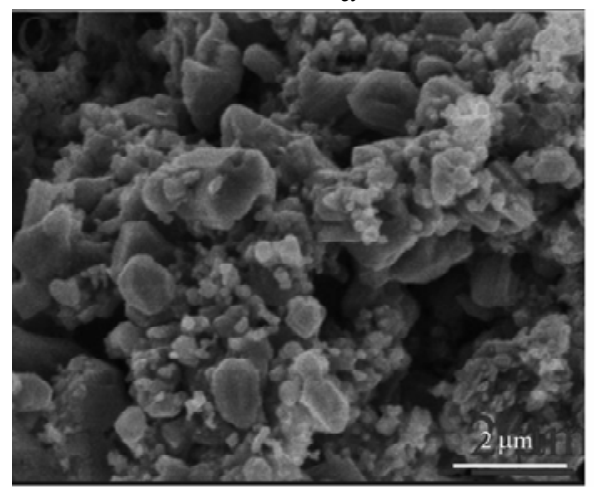

C

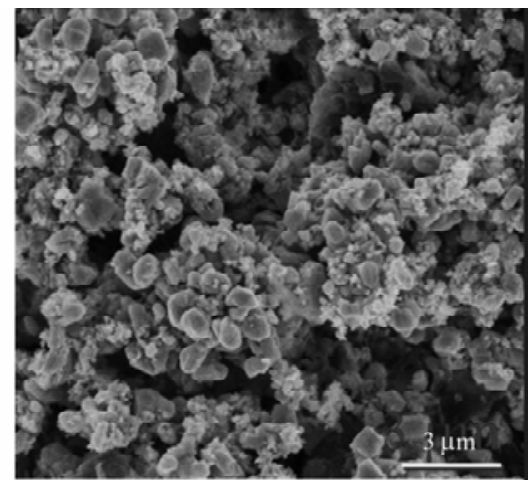

b

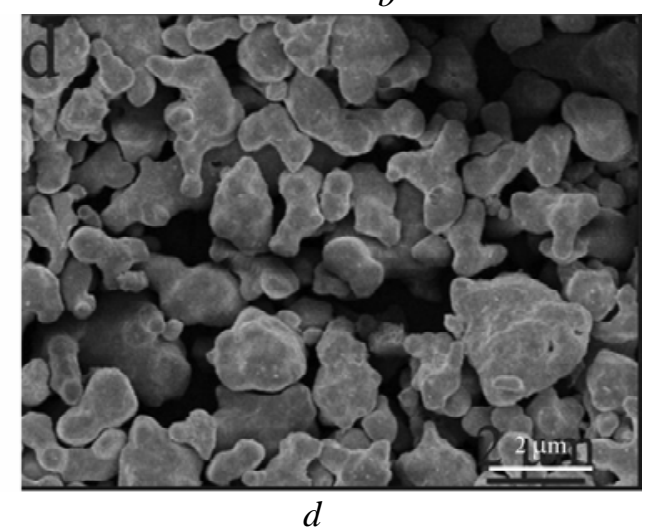

Fig. 2. An overview (a), low $(b)$, middle $(c)$, and high $(d)$ magnification FESEM images of orthorhombic CrB micropaticles.

Figure 3a shows an overview TEM image of the dispersed CrB micropaticles at low magnification. Figure 3, $b$ presents a high magnification TEM image of the sample, revealing that the $\mathrm{CrB}$ architecture is about $1 \mu \mathrm{m}$. The HRTEM image recorded on a single orthorhombic $\mathrm{CrB}$ particle is shown in Fig. 3, $b$ (marked with a circle). The average distance between the neighboring fringes (shown in Fig. 3, c) is about $0.236 \mathrm{~nm}$, corresponding to the (021) plane of orthorhombic CrB. The corresponding SAED pattern (Fig. 3, $d$ ) could be indexed as orthorhombic $\mathrm{CrB}$ (021) (221) and (200) planes. HRTEM and SAED examinations of other CrB microparticles show a similar result, which unambiguously implies their single crystalline nature.

\section{CONCLUSIONS}

In summary, $\mathrm{CrB}$ micropaticles were successfully prepared by the reaction of $\mathrm{Cr}_{2} \mathrm{O}_{3}$ and $\mathrm{NaBH}_{4}$ in an autoclave at $600{ }^{\circ} \mathrm{C}$ for $10 \mathrm{~h}$. The XRD pattern indicated that the product is orthorhombic $\mathrm{CrB}$. The structure and morphology of the obtained product was derived from FESEM, HRTEM and SAED. The sizes of CrB 
micropaticles were about $1-2 \mu \mathrm{m}$. Solid state reactions carried out in sealed autoclave systems provide an alternative, convenient and environmentally friendly pathway for fabrication of metal borides, for the systems can be isolated from air.

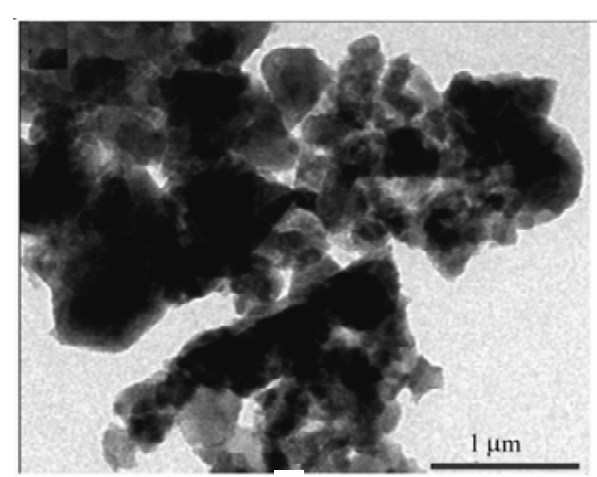

$a$

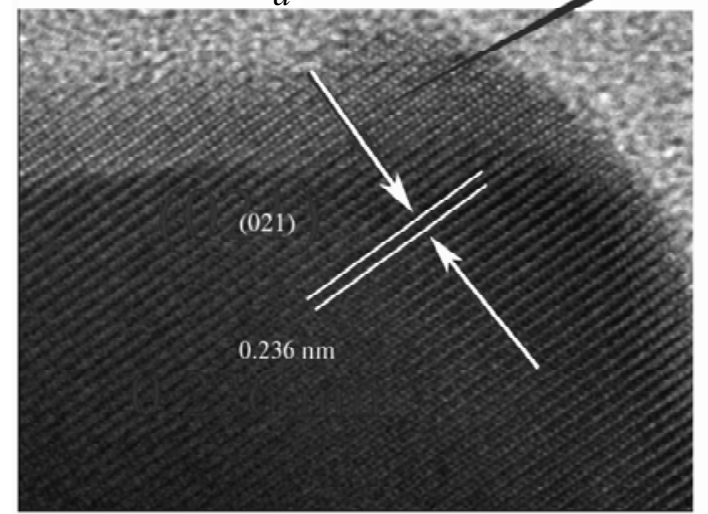

$c$
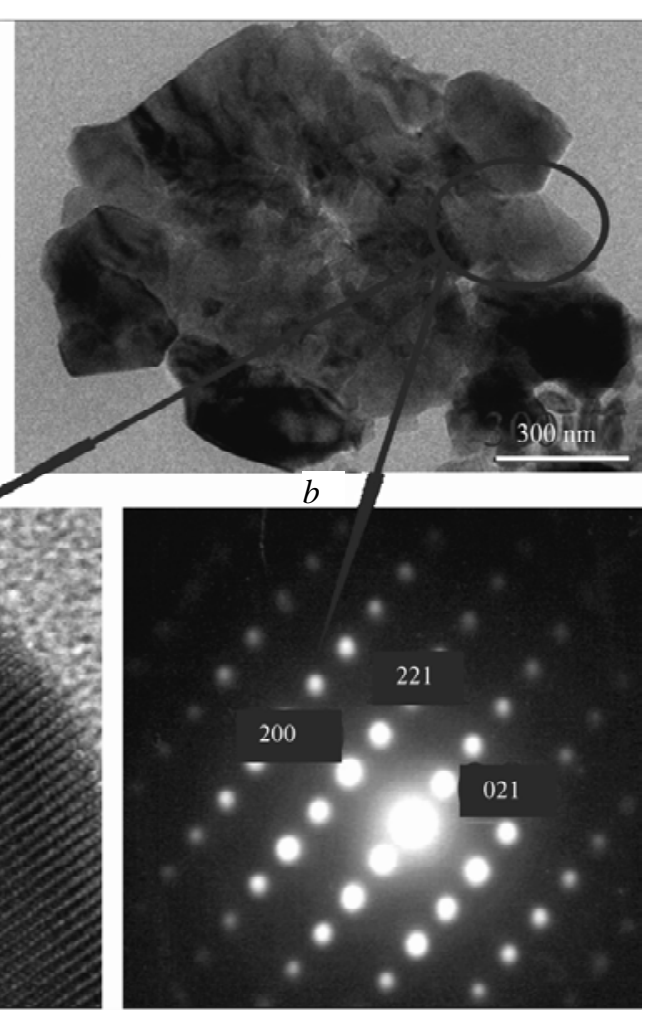

$d$

Fig. 3. TEM images of the CrB $(a, b)$, HRTEM image obtained from the region labeled in $(b)(c)$, corresponding SAED pattern obtained from the region marked in $(b)(d)$.

This work is supported by National Natural Science Foundation of China (No. U1404505), The Program for Innovative Talent in University of Henan Province (16HASTIT010) and Henan Province Projects (14A150047, ZX2014047).

Повідомлясться про новий твердотільний метод синтезу при $600{ }^{\circ} \mathrm{C}$ борида хрому СrВ, який характеризується такими цікавими властивостями, як високі температура плавлення $i$ твердість, опір корозії $i$ абразивного зносу. Діаграма рентгенівської дифракиї продукту реакиії свідчила про те, що продукт є орторомбическим боридом хрому. Розмір ( 1-2 мкм) частинок CrB підтверджується FESEM $і$ TEMзображеннями. Твердотільні реакиії, проведені в герметичних автоклавах, забезпечили альтернативний, зручний, екологічно чистий шлях виробництва $\mathrm{CrB}$.

Ключові слова: твердотільні реакиії, борід хрому, синтез.

Сообщается о новом твердотельном методе синтеза при $600{ }^{\circ} \mathrm{C}$ борида хрома СrВ, который характеризуется такими интересными свойствами, как высокие температура плавления $u$, твердость, сопротивление коррозии и абразивному износу. Диаграмма рентгеновской дифракиии продукта реакичи свидетельствовала о том, что продукт представляет собой орторомбический борид хрома. Размер ( 1-2 мкм) частич CrB подтверждается FESEM- и ТЕМ-изображениями. Твердотельные реакиии, прове- 
денные в герметических автоклавах, обеспечили альтернативный, удобный, экологически чистый путь производства $\mathrm{CrB}$.

Ключевые слова: твердотельнье реакции, борид хрома, синтез.

1. Levine J. B., Tolbert S. H., Kaner R. B. Advances in the search for superhard ultraincompressible metal borides // Adv. Funct. Mater. - 2009. - 19, N 22. - P. 3519-3533.

2. Zhang F. X., Zhang X., Zhang J. X. et al. Synthesis and properties of single crystal Ce1xPrxB6 by floating zone melting // J. Inorg. Mater. - 2014. - 29, N 10. - P. 1073-1076.

3. Portehault D., Devi S., Beaunie P. et al. General solution route toward metal boride nanocrystals // Angew. Chem. Int. Edition. - 2011. - 50, N 14. - P. 3262-3265.

4. Menaka, Kumar Bharat, Kumar Sandeep, Ganguli A. K. Surface decoration through electrostatic interaction leading to enhanced reactivity: Low-temperature synthesis of nanostructured chromium borides (CrB and $\mathrm{CrB}_{2}$ ) // J. Solid State Chem. - 2013. - 200. - P. 117-122.

5. Sonber J. K., Murthy T. S. R., Subramanian C. et al. Investigation on synthesis, pressureless sintering and hot pressing of chromium diboride // Int. J. Refrac. Metals Hard Mater. - 2009. - 27, N 5. - P. 912-918.

6. Castaing J., Danan J., Rieux M. Calorimetric and resistive investigation of the magnetic properties of $\mathrm{CrB}_{2}$ // Solid State Commun. - 1972. - 10, N 6. - P. 563-565.

7. Yeh C. L., Wang J. Z. Formation of chromium borides by combustion synthesis involving borothermic and aluminothermic reduction of $\mathrm{Cr}_{2} \mathrm{O}_{3} / /$ Ceramics Int. - 2012. - 38, N 7. P. 5346-5351.

8.Yeh C. L., Lin J. Z. Effects of boron source on combustion synthesis of chromium boride/ $/ \mathrm{Al}_{2} \mathrm{O}_{3}$ composites // Mater. Manufactur. Proc. - 2013. - 28, N 12. - P. 1335-1339.

9. Audronis M., Kelly P. J., Arnell R. D. Pulsed magnetron sputtering of chromium boride films from loose powder targets // Surf. Coat. Tech. - 2006. - 200, N 15. - P. 4166-4173.

10. Bao L. H., Zhang J. X., Zhou S. L. Effect of Ba-doping on the structural, grain orientation and thermionic emission properties of hexaboride $\mathrm{GdB}_{6} / /$ J. Inorg. Mater. - 2011. - 26, N 10. P. 1116-1120.

11. Menaka J., Sandeep M., Ghanashyam K. M. Multifunctional nanocrystalline chromium boride thin films // Mater. Letters. - 2012. - 73. - P. 220-222.

12. Wang H., Wang W. M., Gu P. et al. Mechanical properties and structure of $\mathrm{TiB}_{2}-\mathrm{NbB}_{2} \mathrm{com}-$ posite prepared by hot pressing // J. Inorg. Mater. - 2002. - 17, N 4. - P. 703-707.

13. Qin L., Zhang X. T., Liang Y. Preparation and characterization of nanocrystalline chromium boride // J. Mater. Sci. - 2006. - 41, N 22. - P. 7617-7619.

14. Ma J. H., Gu Y. L., Shi L. Reduction-boronation route to chromium boride (CrB) nanorods // Chem. Phys. Lett. - 2003. - 381, N 1. - P. 194-198.

15. Zhu Y. C., Li Q. W., Mei T., Qian Y. Solid state synthesis of nitride, carbide and boride nanocrystals in an autoclave // J. Mater. Chem. - 2011. - 21, art. 13756.

16. Kiyokata I., Katsuya K., Shigeru O. Synthesis of chromium borides by solid-state reaction between chromium oxide and amorphous boron powders // J. Ceram. Soc. Jpn. - 1998. - 106, N 9. - P. 931-934.

Received 21.09.15 